\author{
Јелена Пауновић \\ Универзитет у Београду, Филозофски факултет \\ Oдељење за историју \\ e-mail:jpaunovi@f.bg.ac.rs
}

\title{
УТИЦАЈ ПРАВОСЛАВНЕ И КАТОЛИЧКЕ ЦРКВЕ НА УЧЕНЕ ВАЛТАЗАРА БОГИШИЋА
}

Апстракт: Валтазар Богишић је био један од најобразованијих правника југоисточног Балкана у 19. веку. Балдо како су га од миља звали, рођен је 1834. године у Цавтату, далматинском градићу Дубровачке ривијере. Није желео да се бави породичним послом - трговином, већ правом. Као правник, професор права и историчар права, Валтазар Богишић је остварио веома велик допринос развоју правне науке. Био је утемељивач искуствених истраживања обичајног права. У раду се бавимо утицајем иркве на његов животни пут.

Кључне речи: Балтазар Богишић, Цавтат, Дубровник, Одеса, Беч, Црна Гора, кнез Никола I Петровић, Општи имовински законик за Црну Гору, словенско обичајно историјско право, ирква.

Валтазар (Балдо) Богишић представља једну од најважнијих историјскокултуролошких, чак и политичких личности на Балканском простору 19. века. Рођен је у Цавтату, малом приморском граду у близини Дубровника у коме је живело више угледних богатих трговачких породица пореклом из Конавла ${ }^{1}$. Најстарија и најугледнија добростојећа породица је била породица Балтазара Богишића, чији је отац био угледни трговац. Цавтат се налази на рушевинама старог римског насеља под називом Епидаурус и староседеоци га сматрају, укључујући и самог Богишића „колевком Дубровника“. 2 Становници Цавтата су живели грађанским начином живота као и Дубровчани и место су сматрали предграђем Дубровника.

Црква је у почетку имала велики утицај на живот Балтазара Богишића, од првих почетака, школовања до његовог тестамента и саме заоставштине. Сама породица је била изразито патријархалног карактера. Отац се залагао да млади Богишић преузме развијени породични посао - „по очину начелу: образовање према кућној потреби и без одласка из родног мјеста, млади Богишић свршивши основне школе ступи у неку ондашњу приватну школу у Цавтату. Ученика никада није било више од $4-5$; а учитељ је био само један поморски капетан.“ Након очеве смрти, Валтазар Богишић је преузео породични посао, обезбедио је сестру и успео да финансира своје даље школовање.

1 Конавли (Конавле или Конавље) су географска и историјска област на источној обали Јадранског мора, а обухватају крајњи јужни део данашње Далмације, од града Цавтата до полуострва Превлаке 2 Bogišić 1900-1902, 59. 
У Цавтату је постојала једна полу-приватна, полу-јавна школа коју је водио тадашњи жупник Иво Заферон, који је касније постао бискуп у Дубровнику и Шибенику. Богишић је кришом ишао у ову школу пошто се прибојавао очевих критика. За разлику од његових другова Богишићу није било дозвољено да полаже званични завршни испит у Дубровачкој гимназији. О овом периоду живота Богишић наводи следеће: „Познато је уопће како је онда у нашој покрајини забачен био народни српски језик. У уредима и школама о њему ни помена није било. Ћирилица је изван Срба православних, слабо била позната. Важна је чињеница да је управо од Заферона, тог ватреног аутономаша, млади Богишић добио прву књигу из које је научио ћирилицу. Како је био једини у мјесту који је познавао та слова а како онда и турске власти у Босни и Херцеговини, писаху босанском ћирилицом, кад је год цавтатски суд добио отуда писмо о судским послима (а то је често онда бивало особито од Хасан - бега из Требиња) требало је сваки пут замолити младог Богишића да га прочита и протумачи. “3 Ово искуство из младости утицало је на Богишића да успешно започне, разуме и савлада свој каснији дуготрајни рад на Општем имовинском законику за Црну Гору.

Богишић се 1851 . године супротставио оцу и свештенику Заферону када су захтевали да се на породичном гробу на Цавтатском гробљу, презиме Богишић испише на италијанском или латинском језику. Изборио се да му име породице буде уклесано „нашки“. „Он сам својеручно на плочи нацрта натпис а каменар га нареза“. Ово је био први надгробни натпис на Дубровачком приморју исписан на „српском“ језику. ${ }^{4}$

Своје школовање Богишић је наставио под утицајем цркве на Лицеју Св. Катарине у Млецима. Балдо Богишић није прихватао да су Срби и Хрвати два различита народа већ један народ са два различита имена. За себе је говорио „да је Србин српског рода и кољена ... да је рођен католик и да ће као такав и умријети, али да је православна црква једна народна црква, и да њу стога треба и чувати“. Сопственим трудом стекао је веома широко образовање из различитих области друштвено хуманистичких наука. Био је доктор историјских наука, доктор правних наука и doctor honoris hausa на универзитету у Одеси. Говорио је неколико страних језика. Писао је на немачком, француском, руском, италијанском и латинском језику. ${ }^{6}$

Факултетско образовање започео је у Бечу. На самом почетку, а под утицајем дела Еугена Лерминијера ${ }^{7}$, заинтересовао се за „учење права историјском методом“. По завршетку студија права прво дело које је написао било је „Правни обичаји у Словена“ које је издато у Загребу 1867. године и „Напутак за сабирање правних обичаја који у народу живе“. 8 Напутак је имао 239 питања из области приватног права (обитељ, ствари, облигације) и 113 питања из области јавног права (унутрашње државно право, грађански и казнени поступак, казнено право), укупно 352 питања. Иако се Напутак односио само на Јужне Словене, он је убрзо стекао популарност широм словенског света. ${ }^{9}$

У време писања ових дела Богишић је пет година био запослен у Бечкој царској - Придворној библотеци. Исте године када је објавио своја прва дела, у Цавтату су избили

\footnotetext{
3 Исто, 67.

4 Исто, 70.

5 Лицеј Марко Фосцарини је била гимназија - интернат коју је основао Наполеон 1807. године када је Венеција била у његовој власти. Школа се налазила у самостану Св. Катарине и била је нова врста средње школе занована по француском узору. Постојала је до 1867. године.

6 Пуповци 2004, 58.

7 Жан Луис Еуген Лерминијер (1803-1857) био је француски правник и новинар.

8 Bogišić 1900-1902, 79.

9 Bogišić 1900-1902, 106; Spomenica Valtazara Bogišića 1998, 57.
} 
нереди приликом избора за далматински Сабор. У сукобе су били умешани и његови стари знанци и пријатељи. Неки од њих су побегли у иностранство, док су други завршили у затвору. Богишић је прихватио да им помогне и успео је да их ослободи затворских казни. Иако су многи предлагали да Богишић буде делегиран у далматински Сабор, а затим и у аустријски парламент, он је ту понуду одбио. На наговор проте Михаила Фјодоровича Рајевског ${ }^{10}$ Богишић је позван на етнографску изложбу у Москву. Услед унутрашњих проблема у Аустрији, тај пут се није остварио.

После битке код Садове ${ }^{11}$ и пораза Аустрије, аустријска власт је почела да размишља о повећању броја школа и увођењу јавне наставе уместо црквене. Аустријско ратно министарство је установило два нова радна места са титулом „Опћенитог Надзорника са титулом Школског Совјетника“ намењена ,једно за војничку границу хрватску, друго за банатску и сремску“. ${ }^{12}$ Друго намештење, са пребивалиштем прво у Темишвару, а потом у Петроварадину, било је понућено Балду Богишићу, што је он и прихватио. Ово је била војничка служба са чином генералштабског официра.

Богишић је сваки посао радио савесно и одговорно. Унапред се припремао за нову службу. При крају свог боравка у Бечу изучавао је различите педагошке правце и школе, како модерне тако и традиционалне. Саветовао се са Константином Јозефом Јиречеком $^{13}$ и Францом Рихтером фон Миклошичем ${ }^{14}$. Када је стигао у Темишвар, био је подређен „федмаршалајтнату“ Антуну Шмерлингу ${ }^{15}$. Богишићу је на новом положају било омогућено да истражи све школе и образовне установе високог знања и све њихове наставнике и службенике. Као школски надзорник је имао врховну управу над школама у својим рукама. Посетио је и патријаршијску гимназију у Сремским Карловцима „коју му патријарх Маршићевић и, поред потпуне аутономије у школским пословима, зајамчене привилегијама, дозволи да погледа“. Богишић је после овог обимног посла отишао у купалиште Мехадију где је саставио обиман извештај на немачком језику, о стању школа у банатско-сремској регији. На основу овог извештаја, који је имао и комичне примедбе, добио је положај у Бечу као „члан комисије за реорганизацију свих школа цијеле Војничке Границе“. ${ }^{16}$

Балдо Богишић се потом настанио у Новом Саду и у то време је почео редовно да посећује „Биоград“, где се упознао са најпознатијим српским књижевницима Ђуром Даничићем, Јованом Гавриловићем, Јанком Шафариком, Стојаном Новаковићем и својим земљаком Дубровчанином, Матијом Баном. Најважнија је била преписка са Стојаном Новаковићем, који је као министар просвете понудио Богишићу место Шефа катедре права на Београдском универзитету, што је Богишић одбио. Већ тада је почињао истраживања и озбиљан рад на имовинском законику за Црну Гору. Преписка између два научника је била прекинута неколико година. ${ }^{17}$

У Београду је у то време аустро-угарски конзул био Бењамин Калај. Контроверзни аустријски политичар је у то време написао познату Историју српског

10 Михаил Фјодорович Рајевски (1811-1884) је био протојереј, научник, писац, на дужности свештеника цркве при амбасадама Руске империје у Стокхолму, Лондону и Бечу. На тој дужности остао је 42 године, све до смрти, 1884. године.

11 Битка код Садове је била је највећа битка у пруско-аустријском рату. Одиграла се јула 1866. године и окончана је аустријским поразом.

12 Bogišić 1900-1902, 82.

13 Константин Јозеф Јиричек (1854-1918) био је чешки историчар и универзитетски професор.

14 Франц Рихтер Фон Миколишич (1813-1891) био је словеначки и аустријски филолог и лингвиста.

15 Антон фон Шмерлинг (1805-1893) био је аустријски политичар и државник.

16 Bogišić 1900-1902, 84.

17 Недељковић 1968, 1-2. 
народа у којој се више бавио политичким положајем Србије него српском историјом, како у Аутобиографији тврди Балдо Богишић. ${ }^{18}$ Лако је схватити да су Богишићеве мисли тачне ако се прочита увод и закључак Калајевог наведеног дела. У уводу који је упућен „српској публици од писца“ Калај је написао да себи не присваја „непогрешивост“ и тврди да да прихвата сваку исправку. Био је веома заинтересован за српску историју и сам је желео да допринесе њеном тачном расветљењу „живим размењивањем назора и идеја“. Калај је по сопственој тврдњи писао српску историју због својих симпатија према српској држави. У закључку, пак, Калај је написао „После Пожаревачког мира, остаде под Аустријом за двадесетину година један део Србије са Београдом. За тих двадесет година, све је кренуло на боље у тој одавно злопатничкој земљи. И сам се Београд у то доба подиже на таки ступањ развитка, иза којега је још далеко застао у данашње доба. Тим је веће очајање обузело Србе, када су после кратког времена благовања и слободе допали старе невоље и ропства“. ${ }^{19}$ Калајев закључак је потпуно супротан од уводног дела, што је Богишић оправдано приметио. У уводном делу Калај је тврдио да гаји само симпатије за српски народ, док је у закључном делу изнео потпуно супротно виђење. За Калаја је српски народ био робовски народ који је научио да живи само под тиранским режимом.

После поменутих успешних школских реформи у Аустроугарској, Богишић је почео да добија понуде из Кијева, Петрограда и Одесе да се запосли као професор права. Универзитет у Одеси је, као што је већ речено, 1869. године Богишићу дао почасни докторат и он је прихватио запослење као универзитетски професор. Како није довољно добро знао руски језик, морао је да уложи огроман труд да би израдио и изложио приступну беседу на Универзитету у Одеси. У томе је успео, што је изазвало одушевљење присутне публике. Иако се одселио на Црно Море није престао да се бави изучавањем обичајног права у Херцеговини. У Одеси је за своје проучавање нашао „веома знаменит и поуздан извор обавијештења, војводу Луку Вукаловића ${ }^{20}$, гласовитог вођу херцеговачких усташа“. Занимљиво је приметити да је војвода Вукаловић рођен у Требињу тако да је обичајне односе између Требиња, Конавла и Цавтата познавао из прве руке, као и Балдо Богишић.

Богишић је своја истраживања проширио и на област Кавказа, где су живеле многе племенске заједнице које су се са етнографског и социолошког гледишта налазиле на разним нивоима друштвеног и правног развитка. Проучавајући ове народе тумачио је „неке прастаре обичаје који су владали не само код Словена него у Европи у опће“. ${ }^{21}$ Богишић је убрзо добио понуду од црногорског књаза Николе Петровића, по препоруци руског цара Александра II Романова 22 , да започне посао на „цивилном законику према обичајима и потребама“" народа који је живео у Црној Гори. Руски цар је одобрио Богишићу да започне рад на поменутом законику 1872. године. За ово своје достигнуће Богишић је забележио следеће: „Знаменито дјело, чије му извршење би поверено, слагало се потпуно са интелектуалном и научном спремом и снагом нашег професора, као и са његовим природним наклоностима; радило се уистину о решењу до скрајности комплексних проблема, а поред тога о претраживању и утирању новијех путева к сврси

18 Bogišić 1900-1902, 85.

19 Калај 2010, IX-XII, 149.

20 Лука Вукаловић (1823-1873) био је вођа српских устанака у Херцеговини 1852-1862.

21 Bogišić 1900-1902, 87-88.

22 Александар II Николајевич Романов ( 1818-1881) био је руски император од 1855. до 1881. године. 
којој је тежио - у једну ријеч, требало се борити са многим тешкоћама и савладати их. С тога, морамо рећи, да се он у почетку, хотио уклонити сјајној и реткој задаћи која му се повјеравала, особито погледом на моралну одговорност, која је с њом била скопчана“ ${ }^{23}$

Први законик који је донет у Црној Гори био је Законик обшчи црногорски и брдски познатији као Законик Петра I. ${ }^{24}$ Први део Законика од 16 чланова усвојен је Скупштини одржаној 1798. Други део донет је 1803. године на Скупштини на Цетињу. Овај Законик је углавном предстаљао кривични законик јер није регулисао породично-имовинско правне односе. Ситуација у Црној Гори била је специфична, будући да су поглавари државе биле владике, односно духовна лица, током 18. и у првој половини 19. века.

Врховни црквени поглавар у Црној Гори је носио титулу владика, епископ тј. архиепископ Црне Горе. Петар II Петровић Његош ${ }^{25}$ себе је називао „владика црногорски“. Када је укинута Пећка патријаршија 1766. године, дотадашње области српске цркве дошле су под власт Васељенске патријаршије, која није успела да на на место цетињског митрополита доведе Грка. Отуда потичу и наводи да је Цетињска митрополија и црква у Црној Гори стекла аутокефалност. ${ }^{26}$ Однос Православне цркве и црногорске државе мењао се кроз векове у зависности од владара који су били на власти у Црној Гори, као и поглавара који су се налазили на челу епархија Православне цркве. У вези са тим се мењао и положај православног свештенства и верника који су егзистирали на простору Црне Горе. Како су митрополити током периода османлијске власти били једини којима је световни и духовни ауторитет признаван од стране свих племена на простору данашње Црне Горе, највећи део земљишта је био у поседу цркава и манастира. Након престанка теократије и раздвајања световне и духовне власти средином 19. века, однос државе и Цркве остаје јако близак, о чему сведочи законска регулатива црногорске државе донета у периоду након Берлинског конгреса, која је регулисала све аспекте њихове сарадње ${ }^{27}$ Петровић/ Његоши дошли су за митрополите, владике црногорске 1697. године и почели су да присвајају поред духовне и поједине облике световне власти као што је било епископско наследство у породици Петровић/Његош. Тако је било све до прогласа Црне Горе за Кнежевину (1852). Убрзо је донет Законик књаза Данила (1855), који је допринео наставку реформи и изградњи правног друштва у Црној Гори. Укинуо је крвну освету између супротстављених црногорских племена увођењем смртне казне. ${ }^{28}$

Крајем 1882. године књаз Никола ${ }^{29}$ је позвао Богишића у Црну Гору. Због лошег здравља и јаке зиме научник је пристигао у Црну Гору тек марта 1883. где је остао на

23 Bogišić 1900-1902, 91-92.

24 Петар I Петровић Његош, канонизован као Свети Петар Цетињски (1748-1830) био је српски православни митрополит црногорско-приморски и поглавар (Старе) Црне Горе од 1784. до 1830. године, а почевши од 1796. године његово старешинство је признавао и знатан део области Брда. Потписивао се као владика Црне Горе, Скендерије и Приморја.

25 Петар II Петровић Његош (1813-1851) био је српски православни владика црногорски и брдски и поглавар (старе) Црне Горе и Брда од 1830. до 1851. године. Један је од највећих српских песника и филозофа.

26 Љушић 2001, 278-355; Микавица, Васин, Нинковић 2017, 228-272, Слијепчевић 1991, 229 - 294. 27 Арежина 2020, 112. Опширније: Слијепчевић 2002, 145-215.

28 Црногорско-брдски књаз Данило I (1852-1860). Доношењем овог законика, настављене су реформе у циљу изградње савременог државно-правног поретка; Љушић 2001, 299.

29 Никола I Петровић Његош (1841-1921) био је књаз Црне Горе у периоду 1860-1910. и краљ у периоду 1910-1918. из династије Петровић Његош. 
месту министра правде чак шест година. Књаз је примио Богишићеву оставку тек 1896. године. ${ }^{30}$ Истраживање и писање грађанског законика Црне Горе трајало је скоро петнаест година и завршено је 1888. године када је у Црној Гори усвојен Богишићев Општи имовински грађански законик за Кюажевину Црну Гору. Писац је овај законик назвао Општи имовински законик за Црну Гору. Изучавајући природу грађанских односа Богишић је уочио да они нису уједначени већ веома разноврсни. Улога грађанског права од времена старог Рима, током средњег века веома се променила. Из грађанских законика испале су многе правне целине: црква, војска, финасије, кривично право. ${ }^{31}$

Општи имовински грађански законик за Кьажевину Црну Гору има 369 страна и 1031 члан. Богишић се као писац Црногорског законика определио за прихватање идеја илирског и славенофилског покрета. Изучавао је обичајно право Јужних Словена и био је припадник историјско правне школе. Борио се за права вере и самосталност словенских народа на Балкану, посебно Црне Горе. Залагао се за очување културног и ентичког наслеђа Словена. У самом тексту Законика Богишић није могао да не спомене сопствени допринос овом значајном правном делу. За себе је написао „Управ више поменута законика к новоме издању даде згодну прилику да се преузме и ова радња. Прилика је била тим згоднија што је, према жељи Нашој, сам саставилац Законика Г. Др В. Богишић, Наш садашњи министар Правде, могао и ову двоструку задаћу на се лично примити.“32

Законик је у Црној Гори ступио на снагу априла 1888. године. По поменутом правном документу имовинска права су имали сви ,једнаци (једнаки) за хришћанске сваке (све) цркве“. Богишић је сматрао да „тјелесне и душевне разлике међу људима не крње једнакости у имаоништву ни у имовиском праву уопште, јер је та ,једнакост истоветна за мушко и женско, за старо и младо, за здраво и нездраво“ па чак и за нерођено дете. Поштовао је сва људска права, мушкараца, жена, деце, здравих и болесних. Свако je, по Богишићу, ако је хришћанин и да је чак и друге вере, могао да добије наследство. Признавао је права на власништво сваке појединачне породице, државе и цркве.

Богишић је у Аутобиографији свој рад на правном делу од велике важности под називом Општи имовински грађански законик за Књажевину Црну Гору описао као „Величину и големну знаменитост предузећа г. Богишића - предузећа које се обично поверава једној цијелој комисији“"33, а не само професору Богишићу. Богишић је овде опет својој личности и интелекту придао огроман значај у изради овог изузетно важног и значајног правног дела. Био је веома свестан своје памети, научних знања и умећа и својих изузетних интелектуалних способности.

Општи имовински грађански законик за Кьажевину Црну Гору дефинисао је и „власништво непокретних ствари“. Држава је по поменутом законику имала власт над шумом, ако шума није имала власника. По Богишићу, чак и после тридесет година наследник је имао право на наследство. Такође, ако се било које гране надвисе над комшијском земљом или кућом, власник може одмах да од „суједа“ комшије, тражи да те гране уклони. Изузетак чине маслине које се „не смеју сјећи осим ако је то и уколико је у одређеном месту то обичај“. Богишић се бавио свим појединачним сегментима Црногорског имовинског обичајног закона, власништву, купопродаји, продаји, издавању, закупу. Покушао је да све елементе имовинских односа реши појединачно, не према племену и братству, већ према свакој појединачној породици у Црној Гори и свим

30 Bogišić 1900-1902, 98.

31 Spomenica Valtazara Bogišića 2011, 456-469.

32 Богишић 1898 , VIII.

33 Bogišić 1900-1902, 93. 
обичајним ритуалима. Свако, племе, породица или појединац су на основу законика имали право да располажу својим имањем како су могли и желели.

У Општем имовинском законику јасно је дефинисан уговор између сувласника. Међутим чл. 842 даје другачију дефиницију уколико уговор не постоји “Правило је: ко први заузме какву ствар која господара нема, и то с намјером, да његова буде, она већ самим тијем и постаје права влаштина тога заузимаоца. Јасно је дакле, да не може бити заузећа оне ствари која свога власника има“. ${ }^{34}$ Према овом члану могло би се можда закључити да Црна Гора као било световна, било духовна држава чак ни 1898. године није имала јасно дефинистан статус државне и црквене имовине.

Сујед или комшија се може послужити граничним земљиштем у случају да је радња трајна тј. ако комшије користе исти ваздушни простор, ако преко су између својим имања вукли одређење канале, чак су могли да користе заједнички димљак и да ослоне кућу на кућу. Ипак одређује се кад ко има право на туђој ливади да врши испашу стоке, у туђој води да лови рибу, да узима воду из туђег бунара, да прелази преко туђе земље, да у туђој шуми сече дрва, купи жир и друге шумске плодове, да на туђој земљи коси траву, итд. Ово се односи само на период када нема немаштине. У случају оскудице сваки становник има право само своју земљу да користи. ${ }^{35}$ „Кад имаш своју властиту земљу, свог властитог коња, или било коју другу ствар којој си власник, треба да то твоје право поштује, и да те пусти да га на његовој ствари, потпуно и мирно врши“. Ово је члан 870. који почиње да од заједничке одваја личну својину. Законик дефинише и оставу и аманет, тј. наследно право. ${ }^{36}$

Цркве, манастири и други њима слични верски објекти у Црној Гори у власништву су Цркве и верских заједница. Користе се у складу са црквеним уставима и правилима. И ова стечена права не могу се изменити ни једним новим законом нити другим његовим изменама. Овако би препричана на данашњи савремени правнички језик гласила правила која је утемељио др Валтазар Богишић у Општем имовинском законику за Књажевину Црну Гору. Управо у тексту Законика, у поглављу број VIII стоје следеће одредбе:

„О црквама, манастирима и другим њима сличним уредбама вијерским.

Чл. 716. Имаоци су: православне цркве, манастири и друге црквене установе којима ту способност признају црковна правила или црковна Власт, а то признање није у опреци са државним законом. То исто буди речено о црквама и црквеним уредбама других хришћанских вероисповједи које држава познаје.

Чл. 717.

Правило претходног чланка вреди за све нехришћанске богомоље и друга постојана вјерска уређења (на пр. мухамеданске џамије и.т.д.), уколико је држава саму вјеру признала.

Чл. 718.

Управа добара црковних и других имаоника вјерског значаја, као и њихово заступништво направа осталоме свијету бива по уставу њихову, по другим признаним правилима и по наредбама законите им Власти, у колико нијесу у опреци са државним законима." 37

Ове одребе значе да су извршна и законодавна власт на челу са књазом Николом Петровићем признале имовинска и друга стварна права Митрополији црногорскоприморској и брдској. Митрополија корене ових права вуче преко епископије зетске коју

34 Богишић 1898, 304.

35 Исто, 309-311.

36 Исто, 314.

37 Исто, 247-248. 
је још 1219. године основао свети Сава на манастиру на Михољској превлаци. То право на имовину Митрополији и Српској православној цркви признавале су све царевине и краљевине, народна традиција и на крају и сам књаз Никола кроз одребе које је утемељио велики Валтазар Богишић. Колики је велики значај тих стечених права на имовину види се из одредбе члана 1005. Општег имовинског законика за Књажевину Црну Гору у којем се истиче: „Што једном по закону стечеш, тврдо ти је баш и кад би се закон измјенио“.

По завршеном раду на Црногорском имовинском зборнику Богишић је отишао у заслужену пензију и због премора и због свеукупног лошег здравственог стања.

Од књаза Николе је добио посебну захвалницу:

„Драги докторе Богишићу,

Колико год ми је тешко ишити се вашег одличног сатруништва у мојим државнијем пословима одлучио сам милостиво примити оставку коју ми поднијесте на чин Мога министра правде изражене због слвбога ви здравља и изражене ми жеље да остатак својијех година употребите на сређивање вашијех научнијех радова, те да вас данас разрешавам од те дужности.

У пуно заслужени одмор прати вас Моја мајсрдачнија жеља да ви Свемогући укријепи здравље и продужи живот на корист српске књиге и науке, на славу њену и вашу.

Моје Владарско признање за вашу вјерну службу и за зналачке законодавне радове ваше одавно ви је и заувек утврђено. Ја осећам душевно задовољство да вам и сад на растанку поновим то признање и да вам изјавим своју Владарску захвалност. Увјерен да ћете ви и убудуће у даним приликама вашим богатијем знањем и искуством радо и одано ме послужити, остајем

Цетиње 22. фебруар 1899.

Благонаклони вам Никола C.P“.38

Наставио је ипак свој научни рад који је поделио на следећи начин:

„А. Радови о обичајном праву

Б. Радови погледом на издавање правних текстова

Ц. Монографије о правној повјести

Д. Радови о једном предмету, којим се Богишић особито бави, о обитељи и нашљедству: напокон,

Е. Идеја о систематизацији права и о опћим правним питањима, с примјеном“.39

Пред смрт је Балдо Богишић разматрао могућност да се одсели из Париза у Београд и да у Краљевини Србији заснује Задужбину В. Богишића. Богатом Задужбином би управљао Одбор од седам људи и обухватала би целокупну Богишићеву имовину. Богишић је предлагао да се стипендије доделе тројици научника (једном православцу, једном католику и једном мухамеданцу) за усавршавање у иностранству. Научне области које би имале предност приликом финасирања биле су историја, право, умотворине, филогија, итд. ${ }^{40}$ На жалост ова Богишићева жеља није остварена.

Заоставштину је наследила Марија Богишић Похл, контроверзна личност, Богишићева рођена сестра за коју се сумња да је убила сопственог мужа. Богишићеву заоставштину је прво оставила Фрањевачкој цркви Сњежње Госпе у Цавтату, а затим је променила мишљење и препустила музеј и библиотеку Југословенској академији наука и

38 Bogišić 1900-1902, 101.

39 Исто, 104.

40 Архив Богишићевог музеја у Цавтату, Иван Павловић Балтазару Богишићу 11. децембра 1908. године. 
уметности. Заоставштина Балда Богишића данас се налази у Цавтату, у Републици Хрватској и у власништву је Хрватске академије знаности и умјетности.

\section{Архиви}

Архив Богишићевог музеја у Цавтату

\section{Извори}

1. Dr Bogišić Valtazar (1900-1902 [1938]): „Autobiografija, pretisak iz kalendara Dubrovnik", Spomenica Valtazara Bogišića o tridesetogodišnjici njegove smrti, Dubrovnik, 57134.

2. Богишић Балтазар (1898): Општи имовински законик за Кюажевину Црну Гору, друго измијењено и допуњено издање, Цетиње.

3. Valtazar Bogišić (1998): Opšti imovinski zakonik za Knjaževinu Crnu Goru i izabrana djela, приредила Јелена Даниловић, Podgorica - Beograd. Београд.

4. Виктор Новак (1960): Валтазар Богишић и Фрањо Рачки, преписка 1866-1893,

5. Калај фон Бенџамин (2010): Историја српског народа, Београд.

6. Недељковић М. Бранислав (1968): Преписка Стојана Новаковића и Валтазара Богииића, Београд.

\section{Литература}

1. Арежина, Сања (2020): „Анализа имовинско-правних односа између Српске православне цркве и Црне горе у контексту доношења Закона о слободи вјероисповјести или увјерења и правном положају вјерских заједница", Зборник радова Правног факултета у Нишу 88, 111-133.

2. Љушић Радош (2001): Историја српске државности, књ. 2, Нови Сад: Српска академија наука и уметности, огранак у Новом Саду, „Беседа, издавачка установа православне Епархије бачке. Друштво историчара јужнобачког и сремског округа, Нови Сад

3. Микавица, Дејан, Васин, Горан, Нинковић, Ненад (2017): Срби у Црној Гори 1496-1918, Никшић: Иститут за српску културу Подгорица.

4. Пуповци Сурја (2004): Валтазар Богишић. Живот и дјело, Подгорица: Цид

5. Слијепчевић, Ђоко (1991): Историја српске православне цркве 2, Београд.

6. Spomenica Valtazara Bogišića o stogodišnjici njegove smrti 24. april 2008. godine, I-II (2011): Beograd: Službeni glasnik.

7. Uchytil Kružić Vera (2005), Vlaho Bukovac: život i djelo 1855 - 1922, Zagreb: Nakladni zavod Globus. 


\section{Jelena Paunović}

\section{INFLUENCE OF THE ORTHODOX AND CATHOLIC CHURCH ON THE STUDIES OF BALTAZAR BOGISIC}

Baltazar Bogišić was one of the most educated lawyers in southwestern Balkans during the $19^{\text {th }}$ century. Baldo, as was his nick name, was born in 1834 in Cavtat, Dalmatian small town on Dubrovnik Riviera. He did not want to be a part of family business - trade. He wanted to study low. He became an attorney, professor of low and historian of the low. Baltazar Bogišić made a geate contribution to the development of science of low. He was one of the founders of experiential research of the native low. This paper is concerened with the church influence on Bogišićss life path and education. 